\title{
ISTIDLAL FATWA DEWAN SYARIAH NASIONAL TENTANG JUAL BELI EMAS TIDAK TUNAI
}

\author{
Ahmad Zakki Zamani \\ Sekolah Tinggi Agama Islam (STAI) Kuala Kapuas, Kalimantan Tengah \\ Email: zakki.z@yahoo.com
}

Abstract

Fatwa of DSN-MUI No.77 / DSN-MUI / V / 2010 issued on June 3, 2010 states that selling and buying gold with non-cash payment is allowed (mubah) as long as the gold is not as the official medium of exchange (subtituting money) either through purchase or ordinary selling murabaha. This fatwa is controversial among scholars. Some argue that this fatwa is in contrast to the hadiths explaining that it is not allowed to sell an usury item with other item unless it is cash. It also should not be selled by loan although the items are in different types and sizes. The authors are interested in doing research with a focus on two issues, namely: the method of istinbath in a fatwa of DSN law on non-cash trade in gold and its relation with National Sharia Board Fatwa No.77 / DSN-MUI / V / 2010 On Selling and Buying Gold Non-Cash with four Imam sect..

Keywords : Istidlal, Murabaha, Istinbath

\section{Pendahuluan}

Islam telah menentukan aturan-aturan terkait dengan jual beli. Jual beli merupakan suatu perbuatan hukum yang mempunyai konsekuensi terhadap peralihan hak atas suatu benda (barang) dari pihak penjual kepada pihak pembeli, baik itu secara langsung maupun secara tidak langsung (tanpa perantara). Dalam jual beli sudah ditetapkan mengenai rukun dan syarat-syaratnya. Oleh karena itu dalam prakteknya, jual beli harus dilaksanakan berdasarkan ketentuan-ketentuan yang sudah digariskan oleh Islam. ${ }^{1}$

Dalam praktek jual beli di masyarakat, kadangkala tidak mengindahkan hal-hal yang dapat merugikan satu sama lain. Kerugian tersebut ada kalanya berkaitan dengan obyek ataupun terhadap harga. Kerugian ini disebabkan karena ketidaktahuan ataupun kesamaran dari jual beli tersebut. ${ }^{2}$

Praktek jual beli emas yang terjadi pada masa sekarang khususnya di perbankan syariah, sebagian berpendapat jual beli tersebut mengandung unsur ketidaktahuan atau

\footnotetext{
${ }^{1}$ Abdullah Siddiq al-Haji, Inti Dasar Hukum Dalam Islam, (Cet I, Jakarta : Balai Pustaka, 1993), h. 55.

2 H. Fathurahman Djamil, Filsafat Hukum Islam, (bag.I, Cet I, Jakarta : Balai Pustaka, 1997), h.40.
} 
kesamaran terhadap obyek yang telah diperjual belikan, baik penjual maupun pembeli tidak dapat memastikan wujud dari obyek yang telah diperjualbelikan berdasarkan tujuan akad, yakni jual beli emas dengan sistem murabahah atau yang lebih dikenal dengan investasi emas. ${ }^{3}$

Ada salah satu hadis nabi yang kualitasnya shahih menyebutkan tentang pelarang jual beli emas seperti:

"Telah menceritakan Yahya bin Yabya mengatakan saya telab membaca pada Malik dari Nafi' dari Aby Sa'id al Khudri sesungguhnya Rasulullah SAW mengatakan: "janganlah menjual emas dengan emas kecuali sepadan, dan janganlah melebihkean sebagiannya atas sebagian yang lain. Janganlah jual beli sesuatupun dari (emas dan perak) itu yang tidak ada (terbutang) dengan yang ada (tunai)"*

Asbabul wurud mengenai hadist ini adalah ketika Rasulullah ditanya tentang pertukaran antara gandum dengan syair, emas dan perak dengan pembayaran diakhirkan, maka rasulullah pun menjawabnya dengan hadist tersebut. Dalalab/isi kandungan hadist di atas adalah qoth'; mengandung satu makna tentang pelarangan jual beli emas dengan emas, perak dengan perak, gandum dengan gandum, kurma dengan kurma, dan jewawut dengan jewawut kecuali sepadan ataupun ditunaikan

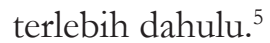

Munculnya fatwa DSN yang masih menimbulkan perdebatan sampai saat ini yaitu fatwa tentang jual beli emas secara tidak tunai No. 77 tahun 2010 yang dikeluarkan pada tanggal 30 Juni 2010 menyatakan hukum mubah melakukan praktek jual beli emas secara tidak tunai. ${ }^{6}$ Dalam fatwa tersebut juga dicantumkan dan dipaparkan beberapa hasil keputusan Rapat Pleno DSN-MUI yang terjadi pada tanggal 20 Jumadil Akhir $1431 \mathrm{H} / 3$ Juni $2010 \mathrm{M}$ yang salah satunya berbunyi :

Jumhur ulama berpendapat bahwa ketentuan atau hukum dalam transaksi sebagaimana dikemukakan dalam hadits Nabi tentang larangan jual beli emas tidak tunai merupakan abkam mu'allalah (hukum yang memiliki 'illat) dan 'illat-nya adalah tsamaniyah, yang mengandung arti bahwa emas dan perak pada masa wurud hadis merupakan tsaman (harga, alat pembayaran atau pertukaran, uang). Dan saat ini, masyarakat dunia tidak lagi memperlakukan emas atau perak sebagai uang, tetapi memperlakukannya sebagai barang (sil'ab). Jadi dapat disimpulkan bahwa dalam dalil fatwa DSN-MUI ini mengambil suatu 'illat hukum terhadap hadis Nabi yang mengartikan emas dengan tsaman.

Pertimbangan lain yang menjadi dasar Fatwa DSN-MUI ini adalah pertimbangan latar belakang sosial budaya, salah satunya adalah kaidah fikih: "Hukum yang didasarkan pada adat (kebiasaan) berlaku bersama adat tersebut dan batal (tidak berlaku) bersamanya ketika adat itu batal, seperti mata uang dalam muamalat". ${ }^{7}$

Kegiatan jual beli emas tidak tunai ini terus berjalan sampai saat ini di perbankan syariah. Munculnya kegiatan investasi atau berkebun emas yang oleh pakar ekonomi

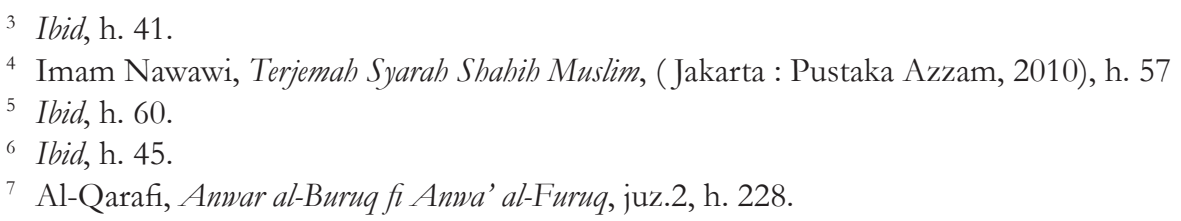


syariah dan fiqh terdapat unsur riba, spekulasi, gharar, disamping itu proses kegiatannya, dalil-dalilnya, maupun fatwa DSN itu sendiri dianggap bermasalah oleh kalangan tertentu.

Dengan adanya permasalahan ini, penulis akan memfokuskan penelitian ini kepada pengambilan dalil illat hukum DSN-MUI mengenai jual beli emas tidak tunai ini agar dapat menemukan solusi berdasarkan petunjuk ilmiah dalam mengungkapkan kebenaran fatwa.

\section{Pembahasan}

\section{Konsep dan Teorti Istidlal \\ Definisi Istidlal}

Secara bahasa, kata istidlal berasal dari kata istadalla yang berarti: minta petunjuk, memperoleh dalil, menarik kesimpulan. Imam al-Dimyathi memberikan arti istidlal secara umum, yaitu mencari dalil untuk mencapai tujuan yang diminta. ${ }^{8}$ Dalam proses pencarian, al-Qurân menjadi rujukan yang pertama, al-Sunnah menjadi alternatif kedua, ijma' menjadi yang ketiga dan qiyas pilihan berikutnya. Apabila keempat dalil belum bisa membuat keputusan hukum, maka upaya berikutnya adalah mencari dalil yang diperselisihkan para ulama, seperti istihsan, mashlahah mursalah, dan lain-lain. Dengan demikian, teori istidlal merupakan pencarian dalil-dalil diluar keempat dalil tersebut. ${ }^{9}$

Definisi di atas menunjukan bahwa seorang mujtahid dalam memutuskan sesuatu keputusan hukum hendaklah mendahulukan al-Qurân, kemudian As-Sunnah, lalu Ijma selanjutnya qiyas. Dan jika Ia tidak menemukan pada al-Qurân, As-Sunnah, Al-'Ijma dan Al-Qiyas, maka hendaklah mencari dalil lain ( Istidlal).

\section{Pembagian Istidlal}

Istidlal terdiri dari dua macam, yaitu Istidlal Qiyasi dan Istidlal Istiqra'i (istiqra'i disebut juga istinbathi) $:^{10}$

a) Istidlal Qiyasi

Menurut Al-Jurzany, pengertian Qiyas adalah sebagai berikut:"penuturan yang tersusun dari keputusan-keputusan (qadhiyah), yang jika keputusan-keputusannya benar, mesti melabirkan suatu kesimpulan (natijab).

Menurut penelitian ahli mantiq, qiyas ada dua macam :Pertama, qiyas iqtirani, kedua, qiyas istisna'i. Qiyas istiqrani adalah: suatu qiyas yang dua muqadimahnya mengandung natijah secara implisit (bil kuwah), tidak eksplisit (bil fi'il). Dan ada bentuk hamli ada yang syarthi. ${ }^{11}$ Qiyas istisnai' adalah qiyas yang natijabnya telah disebutkan atau naqidnya dengan nyata (bil fili). Qiyas istisna'i hanya tersusun dari dua qadiyah syarthiyah. Qiyas istisna'i mempunyai ciri pada kedua qadhiyahnya yaitu terdapatnya adat istisna'i, yakni "lakin"

\footnotetext{
8 Tim Penyusun MKD IAIN Sunan Ampel, Studi Hukum Islam, (Surabaya: IAIN Sunan Ampel Press, 2011), h. 50.

9 Ibid.

${ }^{10}$ Sukriadi Sambas, Mantik Kaidah Berpikir Islam, (Bandung: Remaja Rosdakarya Offset, 1996 ), h, 113.

${ }^{11}$ Iyadl bin Nami As-Silmy, Ushul Figh Alladzi La Yasa' Alfaqibu Jahlabu, (Riyadh: Maktabah AlMamlakat Al-Arabiya, t.th), h. 440.
} 
yang artinya akan tetapi, istisna'i ada yang ittishal artinya (terikat) ada yang infishal (artinya tidak terikat). Bentuk yang bermakna ittishal ada dua $:^{12}$

b) Istidlal Istiqra'i

istidlal Istiqra'i adalah proses berpikir dengan cara menarik suatu kesimpulan umum berdasarkan fakta-fakta setelah terlebih dahulu dilakukan penelitian yang cermat dan tepat. Istilah lain untuk istidlal istiqra'i ini adalah istinbathi (induktif). ${ }^{13}$

Sedangkan Para ulama ushul fiqih, menjelaskan istidlal itu ada beberapa macam, antara lain : istishab, maslahah mursalah, istibsan, saddu z zara'i, ilham. ${ }^{14}$

\section{Konsep dan Teori Istinbath Hukum \\ Pengertian Istinbath}

Istinbath berasal dari kata "nabth" yang berarti : "air yang mula-mula memancar keluar dari sumur yang digali”. Dengan demikian, menurut bahasa, arti istinbath ialah "mengeluarkan sesuatu dari persembunyiannya". ${ }^{15}$ Setelah dipakai sebagai istilah dalam studi hukum islam, arti istinbath menjadi "upaya mengeluarkan hukum dari sumbernya". Makna istilah ini hampir sama dengan ijtihad. Fokus istinbath adalah teks suci ayatayat al-Qurân dan hadis-hadis Nabi s.a.w..Karena itu, pemahaman, penggalian, dan perumusan hukum dari kedua sumber tersebut disebut istinbath. ${ }^{16}$

\section{Bentuk-Bentuk Istinbath Hukum Islam}

a) Metode Bayani

Dalam khasanah ushul figh, metode ini sering disebut dengan al-qawa'idallugawiyyah, atau dilalat al-lafz. Inilah yang disebut dengan metode bayani, yaitu metode istinbath melalui penafsiran terhadap kata yang digunakan dalam nash dan susunan kalimatnya sendiri. Sehingga kaidah-kaidah yang dipakai sebagaimana yang digunakan oleh ulama pakar bahasa Arab. ${ }^{17}$

b) Metode Ta'ili

Metode ini diigunakan untuk mengali dan menetapkan hukum terhadap suatu kejadian yang tidak ditemukan dalilnya secara tersurat dalam nash baik secara qath'i maupun zhanni dan tidak juga ada ijma yang menetapkan hukumnya, namun hukumnya tersirat dalam dalil yang ada, berdasarkan kegunaan dan kedudukannya, illat dibagi menjadi illat tasyri dan illat qiyasi. ${ }^{18}$

c) Metode Istislahi

Metode istislabi adalah penetapan suatu ketentuan berdasarkan asas kemaslahatan yang diperoleh dari dalil-dalil umum, karena untuk masalah tersebut tidak ditemukan dalil-dalil khusus. Jadi biasanya, metode ini baru digunakan bila metode bayani dan ta'lili tidak dapat dilakukan. Dalam menggunakan metode ini ada dua hal penting yang harus diperhatikan, yaitu: kategori pertama, sasaran-sasaran

${ }^{12}$ Al-Khatib Al-Baghdadi, Ahmad bin ali bin Tsabit. Al-Faqih Wa Al-Mutafaqqih, h 208.

${ }^{13}$ Ibid, h.443.

${ }^{14}$ Hamka Haq, Falsafah Ushul Fikih, (Ujung Pandang: Yayasan al-Ahkam, 1998) hm. 203.

${ }^{15}$ Haidar Bagir dan Syafiq Basri, Ijtibad Dalam Sorotan, (Bandung : Mizan Anggota IKAPI, 1996), h. 25.

${ }^{16}$ Romli SA, Muqaranab Mazabib fil Usbul, (Jakarta : Gaya Media Pratama, 1999), h. 1.

${ }^{17}$ Abdul Wahab Khlaf, Ilmu Ușul al-Fiqh, terj. Moh.Zuhri dan Ahmad Qarib (Semarang: Dina Utama. 1994), h 1.

${ }^{18} \mathrm{Ibid}, \mathrm{h} .2$. 
(maqasid) yang ingin dicapai dan dipertahankan oleh syariat melalui aturan-aturan yang dibebankan kepada manusia. Dalam hal ini ada tiga kategori, yaitu daruriyah, hajiyyah, dan tahsiniyah. ${ }^{19}$

\section{Jual Beli Emas Secara Tidak Tunai}

Jual beli secara tidak tunai/kredit adalah cara menjual atau membeli barang dengan pembayaran tidak secara tunai (pembayaran ditangguhkan atau diangsur). ${ }^{20}$ Menurut istilah perbankan yang dimaksud dengan tidak tunai/kredit, yaitu menukar harta tunai dengan harta tidak tunai. ${ }^{21}$

Telah disepakati oleh sebagian besar ulama (ijma), dalam jual beli, emas dan perak dikategorikan sebagai barang ribawi ${ }^{22}$ dikarenakan illat-nya sama yaitu sebagai patokan harga dan merupakan sebagai alat pembayar, yang sama fungsinya, seperti mata uang modern. ${ }^{23}$ Dan dikarenakan sebab itu emas dan perak bisa dijadikan mata uang, sehingga para ulama hadis memahami uang berasal dari emas sebagai mata uang sejenis yaitu emas dengan istilah dan ukuran yang berbeda.

Syarat yang diberikan oleh Islam dalam jual beli emas (dikenal dengan istilah: sharff) tidak bisa ditawar-tawar berdasarkan hadis berikut :

"Jika emas dijual dengan emas, perak dijual dengan perak, gandum dijual dengan gandum, sya'ir (salah satu jenis gandum) dijual dengan sya’ir, kurma dijual dengan kurma, dan garam dijual dengan garam, maka jumlah (takaran atau timbangan) harus sama dan dibayar kontan (tunai). Barangsiapa menambah atau meminta tambahan, maka ia telah berbuat riba. Orang yang mengambil tambahan tersebut dan orang yang memberinya sama-sama berada dalam dosa." (HR. Muslim no. 1584)

Sehingga syarat jual beli emas ada 2 yaitu :

1) Jika emas ditukar dengan emas, maka syarat yang harus dipenuhi adalah (1) yadan bi yadin (harus tunai), dan (2) mitslan bi mitslin (timbangannya sama meskipun beda kualitas).

2) Jika emas ditukar dengan uang, maka syarat yang harus dipenuhi adalah yadan bi yadin (harus tunai), meskipun beda timbangan (nominal).

Implementasi dalil ini dalam konteks kekinian memunculkan ragam persepsi, terutama saat emas atau perak tak lagi diposisikan sebagai media utama bertransaksi. Perbedaan pendapat pun muncul, baik di kalangan ulama salaf atapun khalaf (kontemporer).

Terdapat perbedaan pendapat dikalangan para ulama mazhab tentang jual beli emas secara tidak tunai, ada yang mengharamkan dan ada pula yang membolehkan, dengan penjelasan sebagai berikut :

\footnotetext{
${ }^{19}$ Abdul Wahab Khlaf, Ilmu Ușul al-Figh, terj. Moh.Zuhri dan Ahmad Qarib, h 313.

${ }^{20}$ Tim Penyusun Kamus Pusat Bahasa, Kamus Bahasa Indonesia, Jakarta:Departemen Pendidikan Nasional, 2008), h. 760.

${ }^{21}$ Syuhada Abu Syakir, Ilmu Bisnis \& Perbankan Perspektif Ulama Salafi, h 124.

${ }^{22}$ Benda-benda yang telah ditetapkan ijma' atas keharamannya karena riba ada enam macam yaitu: emas, perak, gandum, syair, dan kurma, dan garam. Syaikh Al-Allamah Muhammad, Fiqh Empat Mą̧hab, (Jakarta: Hasyimi Press, 2010), h.226.

${ }^{23}$ Syuhada Abu Syakir, Ilmu Bisnis \& Perbankan Perspektif Ulama Salafi, h 86.
} 
a. Ulama yang tidak membolehkan jual beli emas secara tidak tunai

Para ulama yang mengharamkan jual beli emas secara tidak tunai adalah para Imam Mazhab (Abu Hanifah, Malik, Syafi'i dan Ahmad Hanbali).

b. Ulama yang membolehkan jual beli emas secara tidak tunai

Para ulama yang membolehkan jual beli emas secara tidak tunai sebagaimana disebutkan dalam fatwa DSN-MUI diantaranya Ibnu Qayyim, Ibnu Taimiyah dan Syekh Ali Jumu'ah, mufti Mesir.

\section{Hukum Jual Beli Emas Tidak Tunai Menurut Para Ulama Pandangan Ulama Empat Mazhab}

Telah disepakati oleh sebagian besar ulama (ijma), emas dan perak dikategorikan sebagai barang ribawi ${ }^{24}$ karena illatnya yaitu sebagai patokan harga dan merupakan alat pembayaran yang fungsinya seperti mata uang modern. ${ }^{25}$ Oleh sebab itu emas dan perak bisa dijadikan mata uang, sehingga para ulama hadis memahami uang berasal dari emas sebagai mata uang sejenis yaitu emas dengan istilah dan ukuran yang berbeda. ${ }^{26}$ Para ulama yang mengharamkan jual beli emas secara tidak tunai adalah para Imam Mazhab (Abu Hanifah, Malik, Syafi'i dan Ahmad Hanbali).Dinyatakan dalam hadis Ubadah bin Shamit ra, beliau berkata :

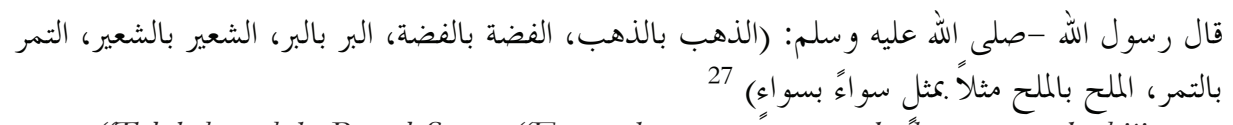

"Telah bersabda Rasul Saw: "Emas dengan emas, perak dengan perak, biji

gandum dengan biji gandum, jewawut dengan jewawut, kurma dengan kurma, garam

dengan garam harus semisal dan sama"

Benda-benda ribawi menurut ijma ada enam, yaitu: emas, perak, gandum, sya'ir, kurma, dan garam. Akan tetapi illat emas dan perak berbeda dengan yang lainnya. Menurut Imam Malik dan Imam Syafi'i illat emas dan perak karena menjadi patokan harga dan yang bisa disamakan dengan uang. ${ }^{28}$ Jika melakukan jual beli emas dan perak mesti diterima masing-masing sebelum berpisah. Dan pendapat ini disetujui pula oleh Imam Malik.

Sedangkan ulama Hanafiyah berpendapat bahwa illat keharaman menjual emas dengan emas dan perak dengan perak secara tidak tunai, ialah benda-benda itu adalah benda-benda yang ditimbang, di samping kesamaan jenisnya, dan haram terhadap empat jenis barang lainnya pula karena benda-benda itu benda-benda yang disukat, dan sama hukumnya. ${ }^{29}$

\footnotetext{
${ }^{24}$ Benda-benda yang telah ditetapkan ijma atas keharamannya karena riba ada enam macam yaitu : emas, perak, gandum, syair, dan kurma, serta garam. Syaikh Al-Alamah Muhammad, fiqh emapat mazhab, (Jakarta : Hasyimi Press, 2010), h. 226.

${ }^{25}$ Syuhada Abu Syakir, Imu Bisnis \& Perbankan Perspektif Ulama Salafi, h. 86.

${ }^{26}$ Idris Ahmad, Fiqh Menurut Mazhab Syafi'i, , h 50.

${ }^{27}$ Hadis, "shahih Muslim", hadis no. 2970 dalam Mausu'at al-Hadis al-syarif, edisi 2, Global Islamic Sofware Company, 1991-1997.

${ }^{28}$ Teungku Muhammad Hasbi Ash-Shiddieqy, Hukum-Hukum Fiqh Islam, (Semarang: Pustaka Rizki Putra, 2001), h.340-343.

${ }^{29}$ Teuku Muhammad Hasbi Ash Shiddieqy, Mutiara Hadis 5, Jilid V ,(Semarang: Pustaka Rizki
} 
Jadi menurut jumhur ulama khususnya Imam Empat Mazhab, bahwa emas dan perak memiliki kesamaan illat, sedangkan kurma, gandum, sya'ir, dan garam juga memiliki illat tersendiri, dan hukumnya haram jika diperjualbelikan secara kredit.

\section{Pandangan Ulama Kontemporer}

Para ulama kontemporer seperti yang disebutkan dalam fatwa DSN-MUI diantaranya Ibnu Qayyim, Ibnu Taimiyah dan Syekh Ali Jumu'ah, mufti Mesir yang membolehkan jual beli emas secara tidak tunai.

Dalil yang digunakan oleh mereka adalah hadis Nabi saw :

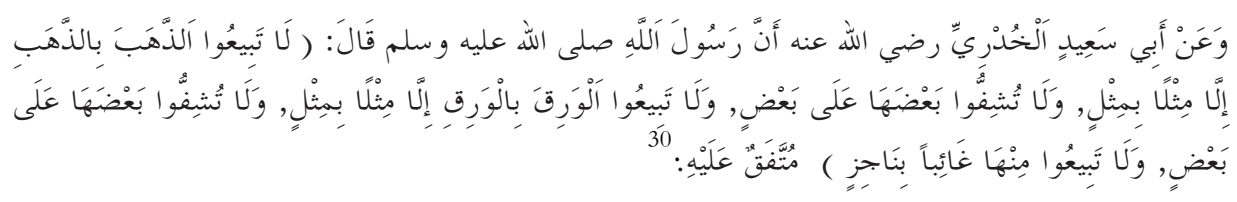

Dari Abu Said Al-Khudry Radliyallaabu'anhu babwa Rasulullah Shallallaabu 'alaibi wa Sallam bersabda: "Janganlah menjual emas dengan emas kecuali yang sama sebanding dan jangan menambah sebagian atas yang lain; janganlah menjual perak dengan perak kecuali yang sama sebanding dan jangan menambah sebagian atas yang lain, dan janganlah menjual perak yang tidak tampak dengan yang tampak." Muttafaq Alaibi

Menurut Syekh Ali Jumu'ah yang dikutip dalam fatwa, emas dalam hadis ini mengandung illah yaitu bahwa emas dan perak merupakan media pertukaran dan transaksi di masyarakat dahulu. Ketika saat ini kondisi itu telah tiada, maka tiada pula hukum tersebut. Ini dikaitkan dengan dengan kaidah ushul :

الحلكم يدور مع علته وجودا و عدما

"bukum itu berputar (berlaku) bersama ada atau tidak adanya "illat".

Ketika saat ini kondisi itu telah berubah, maka tiada pula hukum tersebut, karena hukum berputar (berlaku) bersama dengan 'illat-nya, baik ada maupun tiada.Atas dasar itu, maka tidak ada larangan syara' untuk menjualbelikan emas yang telah dibuat atau disiapkan untuk dibuat dengan angsuran. ${ }^{31}$

Selanjutnya dalam fatwa DSN-MUI mengutip pendapat Ibnu Taymiyah yaitu, "Boleh melakukan jual beli perhiasan dari emas dan perak dengan jenisnya tanpa syarat harus sama kadarnya (tamatsul), dan kelebihannya dijadikan sebagai kompensasi atas jasa pembuatan perhiasan, baik jual beli itu dengan pembayaran tunai maupun dengan pembayaran tangguh, selama perhiasan tersebut tidak dimaksudkan sebagai harga (uang)." 32

Selanjutnya kutipan dari Ibnul Qayyim lebih lanjut menjelaskan, "Perhiasan (dari emas atau perak) yang diperbolehkan, karena pembuatan (menjadi perhiasan) yang diperbolehkan, berubah statusnya menjadi jenis pakaian dan barang, bukan

Putra, 2003), h.262.

${ }^{30}$ CD Room Hadis, "Shabih al-Bukhari", hadis no. 2031 dalam Mausü'at al-Hadìts al-Syarif, edisi 2, Global Islamic Software Company, 1991-1997.

${ }^{31}$ Fatwa DSN-MUI No. 77/DSN-MUI/V/2010 tentang Jual Beli Emas Secara Tidak Tunai, h 4.

${ }^{32}$ Ibid, h 7. 
merupakan jenis harga (uang). Oleh karena itu, tidak wajib zakat atas perhiasan (yang terbuat dari emas atau perak) tersebut, dan tidak berlaku pula riba (dalam pertukaran atau jualbeli) antara perhiasan dengan harga (uang), sebagaimana tidak berlaku riba (dalam pertukaran atau jual beli) antara harga (uang) dengan barang lainnya, meskipun bukan dari jenis yang sama. Hal itu karena dengan pembuatan (menjadi perhiasan) ini, perhiasan (dari emas) tersebut telah keluar dari tujuan sebagai harga (tidak lagi menjadi uang) dan bahkan telah dimaksudkan untuk perniagaan. Oleh karena itu, tidak ada larangan untuk memperjualbelikan perhiasan emas dengan jenis yang sama. ${ }^{33}$

Jadi menurut Ulama Kontemporer emas sudah berubah statusnya menjadi jenis pakaian dan barang, bukan merupakan jenis harga (uang) maka boleh dilakukan jual beli terhadapnya baik jual beli itu dengan pembayaran tunai maupun dengan pembayaran tangguh, selama perhiasan tersebut tidak dimaksudkan sebagai harga (uang).

\section{AnalisisMetode Istinbath Hukum Dewan Syariah Nasional No.77/DSN- MUI/V/2010 Tentang Jual Beli Emas Tidak Tunai}

Metode istinbath yang digunakan DSN-MUI dalam menetapkan fatwa tentang transaksi jual beli emas secara tidak tunai adalah berdasarkan al-Qurân, hadis Nabi Saw, kaidah ushul, kaidah fiqh, dan pendapat para ulama, dengan penjelasan sebagai berikut:

1) Firman Allah SW'T dalm QS Al-baqarah Ayat 275 :

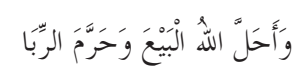

"... Dan Allah telah menghalalkan jual beli dan mengharamkan riba ..."

Lazimnya fatwa-fatwa sebelumnya tentang jual beli yaitu mencantumkan ayat al-Qurân di atas, yaitu dalil al-Qurân yang digunakan merujuk pada dalil induk pembolehan jual beli yaitu QS. al-Baqarah ayat 275.

2)Hadis Nabi Saw

Dalil-dalil dari hadis Nabi Saw ada enam hadis yang digunakan untuk menjadi landasan fatwa, empat diantaranya yaitu :

a) Hadis yang menjelaskan tentang jual beli emas dengan emas haruslah secara tunai.

b) Hadis yang menjelaskan tentang jual beli emas dengan perak adalah riba kecuali dilakukan secara tunai.

c) Hadis tentang larangan menjual emas dengan emas kecuali sama nilainya dan tidak menambah sebagian atas sebagian serta jangan menjual emas dengan perak yang tidak tunai dengan yang tunai.

d) Hadis tentang larangan untuk menjual perak dengan emas secara piutang (tidak tunai)

Empat hadis di atas secara tegas dan eksplisit melarang transaksi emas dengan cara tidak tunai (tangguh/cicil) .

Sedangkan dua hadis lain berkaitan dengan dasar dalam berjual beli yaitu :

a) Hadis tentang jual beli harus berdasarkan kerelaan pihak yang bertransaksi. 
b) Hadis tentang musyawarah dilakukan bukan untuk mengharamkan yang halal atau menghalalkan yang haram.

Kedua hadis diatas menerangkan bagaimana proses musyawarah dalam mengambil sebuah hukum (termasuk hukum berjual-beli), yang mengisyaratkan bahwa pengambilan hukum muamalah dapat dilakukan dengan musyawarah sepanjang tidak mengharamkan yang halal atau menghalalkan yang haram.

Menurut DSN-MUI, saat ini masyarakat dunia tidak lagi memperlakukan emas dan perak sebagai uang, tetapi sebagai barang (sil'ab). Karena itu, jual beli emas dan perak secara tangguh diperbolehkan.Hal inisesuai dengan kaidah ushul yang menjadi landasan DSN-MUI.

3) Kaidah Ushul

Kaidah Ushul dalam fatwa yang digunakan adalah "bukum berputar (berlaku) bersama ada atau tidak adanya 'illat”. Kaidah ini merupakan kaidah dalam syariah yang sifatnyamerupakan kelaziman dalam mengambil hukum.Kaidah ini mereferensi dari buku yang ditulis Ali Ahmad al-Nadawiy.

4) Kaidah Fiqih

DSN-MUI menyebukan 4 kaidah fikih, dimana 3 diantaranya menyebutkan esensi kaidah yang sama yaitu :

a) Adat (kebiasaan masyarakat) dijadikan dasar penetapan hukum.

b) Hukum yang didasarkan pada adat (kebiasaan) berlaku bersama adat tersebut dan batal (tidak berlaku) bersamanya ketika adat itu batal, seperti mata uangdalam muamalat.

c) Setiap hukum yang didasarkan pada suatu 'urf (tradisi) atau adat (kebiasaan masyarakat) menjadi batal (tidak berlaku) ketika adat tersebut hilang. Oleh karena itu, jika adat berubah, maka hukum pun berubah.

Dan yang keempat adalah kaidah dasar dalam bermualah :

d) Pada dasarnya, segala bentuk muamalat boleh dilakukan kecuali adalil yang mengharamkannya.

5) Pendapat Para Ulama Yang Membolehkan

Dalam fatwanya, DSN-MUI juga mendasarkan fatwanya kepada pendapat para ulama yang membolehkan transaksi jual beli emas secara tidak tunai, seperti Ibnu Taimiyah, Ibnu Qayyim dan ulama kontemporer yang sependapat. Mereka mengemukakan Bahwa Pertama, emas dan perak adalah barang (sil'ab) yang dijual dan dibeli seperti halnya barang biasa, dan bukan lagi tsaman(harga, alat pembayaran, uang).Emas dan perak setelah dibentuk menjadi perhiasan berubah menjadi seperti pakaian dan barang, dan bukan merupakan tsaman(harga, alat pembayaran, uang). Oleh karenanya tidak terjadi riba (dalam pertukaran atau jual beli) antara perhiasan dengan harga (uang), sebagaimana tidak terjadi riba (dalam pertukaran atau jual beli) antara harga (uang) dengan barang lainnya, meskipun bukan dari jenis yang sama. $^{34}$

Kedua, Pada zaman ini manusia sangat membutuhkan untuk melakukan jual beli

${ }^{34}$ Fatwa DSN_MUI Nomor:77/DSN-MUI/V/2010, h 9. 
emas. Apabila tidak diperbolehkan jual beli emas secara angsuran, maka rusaklah kemaslahatan manusia dan mereka akan mengalami kesulitan. Sekiranya pintu (jual beli emas secara angsuran)ini ditutup, maka tertutuplah pintu utang piutang, masyarakat akan mengalami kesulitan yang tidak terkira. ${ }^{35}$

Dengan demikian, dalam penetapan fatwa tentang jual beli emas secara tidak tunai DSN-MUI mengacu pada prosedur penetapan metode Istidlal kemudian diistinbathkan dengan hukum mubah dalam jual beli emas tidak tunai, metode yang digunakan DSN yaitu metode Istinbath Istislahi yaitu penetapan suatu ketentuan berdasarkan asas kemaslahatan yang diperoleh dari dalil-dalil umum, karena untuk masalah tersebut tidak ditemukan dalil-dalil khusus. Hal ini semata-mata untuk menjaga bahwa fatwa yang dikeluarkan DSN secara jelas dapat diketahui sumber atau dalil-dalil yang digunakan serta melalui kaidah-kaidah dalam mengeluarkan fatwa.

Analisis Relevansi Fatwa Dewan Syariah Nasional No.77/DSN-MUI/V/2010 Tentang Jual Beli Emas Tidak Tunai Dengan Ulama Empat Imam Mazhab Analisis Pandangan Ulama Empat Imam Mazhab Tentang Jual Beli Emas Tidak Tunai

Jumhur ulama sepakat berdasarkan hadis-hadis nabi tentang jual beli emas, maka disimpulkan benda-benda yang diharamkan riba yang dinashkan dengan ijma ada enam, yaitu: emas, perak, gandum, sya'ir, kurma, dan garam, akan tetapi illat emas dan perak berbeda dengan yang lainnya.

Menurut Imam Malik dan Imam Syafi'i dikarenakan illat barang itu dijadikan patokan harga dan benda-benda tersebutlah yang hanya bisa disamakan dengan uang. ${ }^{36}$ Menurut Imam Syafi'i illat keharaman yang demikian hanya dengan emas dan perak saja.Jika melakukan jual beli atasnya mesti diterima masing-masing sebelum berpisah. Dan pendapat ini disetujui Imam Malik.

Menurut ulama Hanafiyah berpendapat bahwa illat keharaman menjual emas dengan emas dan perak dengan perak secara tidak tunai, ialah benda-benda itu adalah benda-benda yang ditimbang, di samping kesamaan jenisnya, dan haram terhadap empat jenis barang lainnya pula karena benda-benda itu benda-benda yang disukat, dan sama hukumnya. ${ }^{37}$

Imam Ahmad bin Hanbal menjadikan hadis tersebut sebagai sebab (illat) dimana emas dianggap sebagai takaran atau timbangan dalam jenis yang sama karena terwujudnya sebab berdasarkan riwayat Ibnu Umar bahwasanya Rasulullah Saw bersabda :

"jangan kalian menjual satu dinar dengan dua dinar, jangan pula menjual satu dirham dengan dua dirham, dan jangan pula satu sha' dengan dua sha".

Keempat hadis yang melarang berjual beli emas secara tidak tunai ini telah menegaskan betapa spesialnya emas sebagai sebuah benda, sehingga tata cara mentransaksikannya diingatkan begitu rinci oleh Nabi Saw. Mengingat emas adalah

\footnotetext{
${ }^{35}$ Ibid.

36 Teungku Muhammad Hasbi Ash-Shiddieqy, Hukum-Hukum Figh Islam,, hal.340-343.

${ }^{37}$ Teuku Muhammad Hasbi Ash Shiddieqy, Mutiara Hadis 5, Jilid V , , hal.262.
} 
logam mulia yang secara kebendaan memiliki sifat kualitas yang stabil sehingga melekat padanya fungsi sebagai benda yang menyimpan nilai dan sebagai pengukur nilai barang lain, sehingga emas menjadi benda yang paling pantas menjadi alat pertukaran atau uang.

Imam Syafi'i dan Imam Malik menginterpretasikan hadis riba tersebut secara berbeda. Dalam pandangan mereka, dua jenis pertama mewakili penentu harga (tsaman) sedangkan empat jenis barang yang lain terkait dengan makanan. Dengan paham ini segala bentuk jual beli yang dibayar dengan uang secara hukum dibenarkan. Menurut Imam Syafi'i uang tidak bisa dikategorikan ke dalam makilat maupun mauzunat, melainkan terpisah sama sekali dari jenis barang lainnya berdasarkan kesepahaman antar pengguna uang tersebut. Lebih jauh karena semua barang bisa menjadi alat tukar atau memiliki sifat sebagai alat tukar (tsamaniya), pendapat Imam Syafi'i tersebut memberikan banyak kebebasan dan lebih pragmatis. Pendapat ini juga memiliki alasan praktis bahwa jual beli bahan makanan dengan uang pasti dibolehkan karena juga didukung oleh hadis Rasulullah SAW, "Cara yang berguna bagi seseorang untuk memperoleh penghidupan". 38

Konsep Imam Syafi'i mengenai tsamaniah membuka konsep baru tentang uang, uang tidak lagi menjadi komoditi-berbeda dengan emas dan perak dalam bentuk aslinya. Orang memegang uang karena uang mudah dipakai untuk membeli kebutuhan apa saja yang dibutuhkan manusia. Nilai uang adalah berdasarkan kesepakatan dan tidak lagi terbatas pada nilai intrinsik yang terkandung dalam logam yang dipakai untuk membuat uang tersebut. Meskipun demikian Imam Syafi'i sendiri lebih condong untuk menimbang uang berdasarkan berat dibandingkan dengan menghitungnya, hal ini didorong oleh kebiasaan masyarakat pada zamannya yang begitu kuat memegang tradisi untuk menimbang uang. Karena kebiasaan ini, maka yang dikategorikan riba pada masa tersebut adalah apabila jumlah berat yang berbeda dan bukannya dengan jumlah hitungan yang berbeda.

Jika dikaitkan dengan metode istidlal dan istinbath hukum yang dilakukan oleh para ulama empat mazhab, hanya melakukan kajian fahmul hadis (pemahaman hadis) secara tekstual dengan menyandarkan beberapa pendekatan historis seperti asbababul wurud hadis, dan pengambilan illat hukum emas yang masih tetap sebagai tsaman. Dapat disimpulkan dari pendapat imam empat mazhab, walaupun uang dan emas adalah dua jenis yang berbeda, akan tetapi keduanya mempunyai illat yang sama yaitu mempunyai nilai tukar. Karenanya keduanya boleh ditukarkan dengan syarat harus kontan.

\section{Analisis Fatwa DSN/MUI NOMOR:77/DSN-MUI/V/2010 tentang Kebolehan Jual-Beli Emas Secara Tidak Tunai}

Menurut DSN-MUI hadis tentang pelarangan jual beli emas tidak tunai mengandung illat bahwa emas dan perak merupakan media pertukaran dan transaksi di masyarakat pada masa dahulu. Ketika saat ini kondisi itu telah berubah, perubahan kondisi menyebabkan perubahan hukum.

\footnotetext{
${ }^{38}$ Abdullah Bin Abdurrahman, Taisirul Allam Syarah 'Umdatul Abkam, terj. Fathul Mujib, Taisirul 'Allam Syarhu Umdatil Ahkam. h. 205
} 
Dalam fatwanya, DSN-MUI juga mendasarkan fatwanya kepada pendapat para ulama yang membolehkan transaksi jual beli emas secara tidak tunai, seperti Ibnu Taimiyah, Ibnu Qayyim dan ulama kontemporer yang sependapat. Mereka mengemukakan bahwa, emas dan perak adalah barang (sil'ab) yang dijual dan dibeli seperti halnya barang biasa, dan bukan lagi tsaman (harga, alat pembayaran, uang). Emas dan perak setelah dibentuk menjadi perhiasan berubah menjadi seperti pakaian dan barang, dan bukan merupakan tsaman (harga, alat pembayaran, uang). Oleh karenanya tidak terjadi riba (dalam pertukaran atau jual beli) antara perhiasan dengan harga (uang), sebagaimana tidak terjadi riba (dalam pertukaran atau jual beli) antara harga (uang) dengan barang lainnya, meskipun bukan dari jenis yang sama. ${ }^{39}$

\section{Relevansi Fatwa Dewan Syariah Nasional No.77/DSN-MUI/V/2010 Tentang Jual Beli Emas Tidak Tunai Dengan Ulama Empat Imam Mazhab}

Dalam hal jual beli emas secara tidak tunai para ulama berbeda pendapat di antaranya Pertama melarang; dan ini pendapat mayoritas fuqaha, dari mazhab Hanafi, Maliki, Syafi'i, dan Hambali. Kedua membolehkan; dan ini pendapat Ibnu Taimiyah, Ibnu Qayyim dan ulama kontemporer yang sependapat.

Jika ditelusuri lebih dalam lagi, disini terjadi perbedaan pandangan mengenai illat pada obyek jual belinya yaitu emas. Dan DSN-MUI menggunakan pada pendapat Ibnu Taimiyah dan Ibnu Qayyim yang membolehkan jual beli emas secara tidak tunai, Ibnu Taimiyah berpendapat,"Boleh melakukan jual beli perhiasan dari emas dan perak dengan jenisnya tanpa syarat harus sama kadarnya (tamatsul), dan kelebihannya dijadikan sebagai kompensasi atas jasa pembuatan perhiasan, baik jual beli itu dengan pembayaran tunai maupun dengan pembayaran tangguh, selama perhiasan tersebut tidak dimaksudkan sebagaiharga (uang)." ${ }^{\prime 40}$

Imam Syafi'i berpendapat bahwa menjual emas dan perak (lain jenis) dengan berbeda lebih banyak adalah boleh, tetapi jika sejenis (emas dengan emas) tidak diperbolehkan dengan kata lain riba, sedangkan Imam Syafi'i mensyaratkan agar tidak riba yaitu sepadan (sama timbangannya, takarannya dan nilainya) spontan dan bisa diserah terimakan. Dan mereka sepakat bahwa jual beli mata uang harus dengan syarat tunai, tetapi mereka berbeda pendapat tentang waktu yang membatasi. Imam Hambali dan Syafi'i berpendapat bahwa jual beli mata uang terjadi secara tunai selama kedua belah pihak belum berpisah, baik penerimanya pada saat transaksi atau penerimaannya terlambat. Tetapi imam Maliki berpendapat jika penerimaan pada majelis terlambat, maka jual beli tersebut batal, meski kedua belah pihak belum berpisah.

Emas dan uang kertas itu sama pada dasarnya hal itu dikarenakan emas diterima oleh masyarakat sebagai alat penukar tanpa perlu dilegalisasi oleh pemerintah (bank sentral), sedangkan uang kertas diterima sebagai alat penukar karena pemerintah mengatakan behwa uang kertas itu adalah alat pembayar yang sah. ${ }^{41}$

\footnotetext{
39 Fatwa DSN-MUI Nomor:77/DSN-MUI/V/2010, h 9.

${ }^{40}$ Ibid, h. 11.

${ }^{41}$ Prathama Rahardja, Uang Dan Perbankan, (Jakarta: Rineka Cipta,Cet-III, 1997), h. 11.
} 
Dalam hal inilah kita dapat melihat bahwa uang dapat mengambil bentuk barang yang nilainya dianggap sesuai dengan kemampuan tukarnya.Emas dan perak memiliki nilai yang dianggap sebagai komoditas untuk menyimpan kekayaan.Ibnu Khaldun menulis, tuhan menciptakan dua logam mulia (emas dan perak) itu untuk menjadi alat pengukur nilai/ harga bagi segala sesuatu. ${ }^{42} \mathrm{Al}$-Maqrizi dalam Ighatsah menambahkan, tuhan menciptakan dua logam mulia itu bukan sekedar sebagai alat pengukur nilai, atau untuk menyimpan kekayaan, tapi juga sebagai alat tukar. ${ }^{43}$ Para ulamamazhab yang berpendapat demikian itu ialah Imam Malik, Ahmad dan sebagian ulama Syafi'iyyah. Alasan mereka ialah karena dengan cara demikian itu agar tercapai tujuan agama Islam mencegah riba dan menutup kemungkinan dari praktek riba itu. ${ }^{44}$

Agar dapat mengamati secara jelas perbedaan yang terjadi antara ulama empat Mazhab dan DSN yang mengambil rujukan ulama kontemporer, maka penulis membuat tabel sebagai berikut:

\section{Pemahaman Hadis Jual Beli Emas antara DSN dan Ulama Empat Mazhab}

\begin{tabular}{|c|c|c|c|}
\hline No & $\begin{array}{c}\text { Hadis-Hadis Yang } \\
\text { Dijadikan Dalil Jual Beli } \\
\text { Emas }\end{array}$ & DSN-MUI & Ulama Empat Mazhab \\
\hline 1 & $\begin{array}{l}\text { Dari 'Ubadah bin Shamit, } \\
\text { Nabi s.a.w. bersabda: "Jual } \\
\text { beli) emas dengan emas, perak } \\
\text { dengan perak, gandum dengan } \\
\text { gandum, sya'ir dengan sya'ir, } \\
\text { kurma dengan kurma, dan } \\
\text { garam dengan garam (dengan } \\
\text { syarat harus) sama dan sejenis } \\
\text { serta secara tunai.Jika } \\
\text { jenisnyaberbeda, juallah } \\
\text { sekehendakmu jika dilakukan } \\
\text { secara tunai. }\end{array}$ & 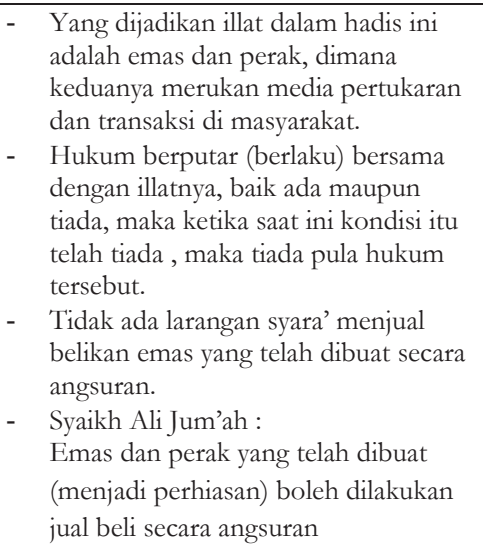 & $\begin{array}{l}\text { - Jumhur ulamar sepakat } \\
\text { benda-bendaryang } \\
\text { diharamkan radis ada } \\
\text { berdasarkan hadis } \\
\text { enam, yaitu: emas, perak, } \\
\text { gandum, sya'ir, kurma, dan } \\
\text { garam, akan tetapi illat } \\
\text { emas dan perak berbeda } \\
\text { dengan yang lainnya. } \\
\text { - Imam Syafi'i dan Imam } \\
\text { Malik: } \\
\text { illatkeharaman pada hadis } \\
\text { hanya dengan emas dan } \\
\text { perak saja. Jika melakukan } \\
\text { jual beli atasnya mesti } \\
\text { diterima masing-masing }\end{array}$ \\
\hline 2 & $\begin{array}{l}\text { Dari Umar bin Khatthab, } \\
\text { Nabi s.a.w. bersabda: "Jual } \\
\text { beli) emas dengan perak adalab } \\
\text { riba kecuali(dilakukan) secara } \\
\text { tunai." }\end{array}$ & $\begin{array}{l}\text { - } \quad \text { Syaikh Abdullah bin Sulaiman al-Mani } \\
\text { : } \\
\text { Emas dan perak yang sudah dibentuk } \\
\text { perhiasan sudah keluar dari fungsi } \\
\text { sebagai tsaman, maka boleh dilakukan } \\
\text { dengan tidak tunai. } \\
\text { - } \quad \text { Ibnu Taimiyah : } \\
\text { Boleh melakukan jual beli emas dan } \\
\text { perak selama dibentuk menjadi } \\
\text { perhiasan (bukan emas batangan) baik } \\
\text { dilakukan secara tunai maupun tidak. } \\
\text { - } \quad \text { Ibnu Qayyim : }\end{array}$ & $\begin{array}{l}\text { sebelum berpisah } \\
\text { - Ulama Hanafiyah: } \\
\text { berpendapat bahwa illat } \\
\text { keharaman menjual emas } \\
\text { dengan emas dan perak } \\
\text { dengan peraksecara tidak } \\
\text { tunai, ialah benda-benda } \\
\text { itu adalah benda-benda } \\
\text { yangditimbang. } \\
\text { Imam Ahmad bin Hanbal: } \\
\text { sebab (illat) } \\
\text { dalam hadis ini dimana } \\
\text { emas dianggap sebagai } \\
\text { takaran atau timbangan }\end{array}$ \\
\hline
\end{tabular}

${ }^{42}$ Ahmad Riawan Amin, Satanic Finance, (Jakarta: Pt.Ufuk Publising House, 2012), h. 92.

${ }^{43} \mathrm{Ibid}$.

${ }^{44}$ As Shan'ani, Terjemahan Subulussalam, Jilid III, terj. Abu Bakar Muhammad, Subulus Salam III, (Surabaya : Al-Ikhlas, 1995), h. 142. 


\begin{tabular}{|c|c|c|c|}
\hline 3 & $\begin{array}{l}\text { Dari Abu Sa'id al-Khudri, } \\
\text { Nabis.a.w. bersabda: } \\
\text { "Janganlah kamu menjual emas } \\
\text { dengan emas kecuali } \\
\text { sama(nilainya) dan janganlah } \\
\text { menambabkan sebagian } \\
\text { atassebagian yang lain; } \\
\text { janganlah menjual perak dengan } \\
\text { perakkecuali sama (nilainya) } \\
\text { dan janganlab } \\
\text { menambabkansebagian atas } \\
\text { sebagian yang lain; dan } \\
\text { janganlah menjualemas dan } \\
\text { perak. tersebut yang tidak tunai } \\
\text { dengan yangtunai." }\end{array}$ & $\begin{array}{l}\text { Pembuatan emas dan perak menjadi } \\
\text { perhiasan telah keluar ari tujuannya } \\
\text { sebagai harga dan telah dimaksudkan } \\
\text { untuk perniagaan, maka tidak ada } \\
\text { larangan untuk memperjual belikan } \\
\text { sejenis secara tidak tunai. }\end{array}$ & $\begin{array}{l}\text { dalam jenis yang sama } \\
\text { karena terwujudnya sebab. }\end{array}$ \\
\hline $\begin{array}{l}\text { Ikhti } \\
\text { l-af }\end{array}$ & & $\begin{array}{l}\text { Kebolehan jual beli emas tidak tunai } \\
\text { selama emas tersebut dibentuk dan } \\
\text { dijadikan perhiasan. }\end{array}$ & $\begin{array}{l}\text { Keharaman emas disebabkan } \\
\text { emas bukan sebagai dan } \\
\text { dijadikan barang (sila'). }\end{array}$ \\
\hline \multicolumn{2}{|c|}{$\begin{array}{c}\text { Al Jam'u wa at-Taufiq } \\
\text { Dengan metode Istidlal Qiyashi } \\
\text { Istisna'i }\end{array}$} & \multicolumn{2}{|c|}{$\begin{array}{l}\text { Emas perhiasan boleh dijualbelikan tidak tunai, dan Emas bukan perhiasan } \\
\text { haram dijualbelikan tidak tunai. }\end{array}$} \\
\hline
\end{tabular}

Dari tabel diatas penulis memberikan perbandingan yang menjadi letak perbedaan dalam memahami hadis yang dijadikan dalil sebagai pelarangan jual beli emas tidak tunai.Dan dapat disimpulkan bahwa letak perbedaan tersebut terdapat pada penetapan illat emas itu sendiri baik sebagai harga maupun sebagai barang.

Kemudian setelah penulis membuat kesimpulan statement terhadap masingmasing pendapat baik DSN yang mengambil pendapat Ulama kontemporer dan Ulama empat mazhab.Maka penulis berpendapat kedua kelompok tersebut masing-masing memberikan pendapat dengan dalil-dalil yang rajih (kuat).

Agar dapat menghilangkan perbedaan tersebut maka penulis melakukan metode Al-jam'u wat Taufiq yaitu menghubungkan dua dalil yang Nampak bertentangan, sehingga keduanya bisa dipakai dan diamalkan dengan didapatkan makna yang berserasian.

Maka untuk melakukan prosestersebut penulis menggunakan jalan Istidlal Qiyashi Istisna'i yang telah diambil kesimpulan statement yaitu :

Emas perbiasan boleh dijualbelikan tidak tunai, dan Emas bukan perbiasan haram dijualbelikan tidak tunai

Tetapi Emas perhiasan $=$ boleh tidak tunai

Akan tetapi emas bukan perhiasan $=$ tunai

Jadi antara fatwa DSN dan Ulama Empat mazhab pada dasarnya tidak ada perbedaan atau ikhtilaf pendapat tentang kebolehan jual beli emas tidak tunai, baik ulama kontemporer yang dirujuk DSN maupun ulama empat imam mazhab saling melengkapi dalam menjelaskan makna pemahaman hadis tersebut. Dimana selama emas tersebut tidak dijadikan perhiasan (barang) maka dalam melakukan jual belinya harus tunai sedangkan jika dijadikan perhiasan maka boleh dijualbelikan secara kredit. 


\section{Simpulan}

Berdasarkan hasil pengamatan serta membanding pendapat DSN-MUI dan Empat Imam Mazhab, dimana DSN mengambil rujukan dari pendapat Ulama kontemporer seperti Ibnu Taimiyah, Ibnu Qayyim, Syaikh Ali Jum'ah yang berpendapat bahwa emas dan perak yang sudah dibentuk menjadi perhiasan adalah barang (sil'ab) yang dijual dan dibeli seperti halnya barang biasa dan bukan merupakan tsaman (harga, alat pembayaran, uang), sedangkan pendapat ulama empat Imam Mazhab sepakat bahwa emas yang bukan perhiasan dalam jual belinya disyaratkan tunai dan emas termasuk kedalam barang ribawi. Penulis berpendapat kedua kelompok tersebut masing-masing memberikan pendapat dengan dalil-dalil yang rajih (kuat). Dengan menggunakan metode al-jam'u wat taufiq yaitu menghubungkan dua dalil yang nampak bertentangan, sehingga keduanya bisa dipakai dan diamalkan dengan didapatkan makna yang berserasian dengan menggunakan jalan Istidlal Qiyashi Istisna'i dapat disimpulkan:

Emas perbiasan boleh dijualbelikan tidak tunai, dan Emas bukan perbiasan haram dijualbelikan tidak tunai

$$
\begin{aligned}
& \text { Tetapi Emas perhiasan }=\text { boleh tidak tunai } \\
& \text { Akan tetapi emas bukan perhiasan }=\text { tunai }
\end{aligned}
$$

Jadi antara fatwa DSN dan ulama empat mazhab pada dasarnya tidak ada perbedaan atau ikhtilaf tentang kebolehan jual beli emas tidak tunai, baik ulama kontemporer yang dirujuk DSN maupun ulama empat imam mazhab saling melengkapi dalam menjelaskan makna pemahaman hadis tersebut. Dimana selama emas tersebut tidak dijadikan perhiasan (barang) maka dalam melakukan jual belinya harus tunai sedangkan jika dijadikan perhiasan maka boleh dijualbelikan secara kredit.

\section{Daftar Pustaka}

Abdullah Bin Abdurrahman, Taisirul Allam Syarah 'Umdatul Abkam, terj. Fathul Mujib, "Taisirul 'Allam Syarhu Umdatil Abkam", (Malang: Cahaya Tauhid Press, Cet.VII, 2010).

Ahmad, Imam bin Husain, Fathu al-Qorib al-Mujib, (Surabaya : Al-hidayah).

Ahmad, Idris, Fiqh Menurut Mąhab Syafi', (Jakarta: Widjaya Jakarta, 1974).

Al-Albani, Syaikh Muhammad Nashiruddin, Shabih Sunan Ibnu Majah, (Jakarta : Pustaka Azzam, 2005).

Al-Asqalani, Ibnu Hajar, BulugulMaram, terjemahan A. Hasan (Bandung : Diponegoro, 2000).

Antonio, Mohammad Syafi'i, Bank Syari'ah dan Teori dan Praktek, (Jakarta: Gema Insani Press, 2003).

Anshori, Abdul Ghofur, Perbankan Syariah Di Indonesia, (Cet II, Yogyakarta: Gadjah Mada University Press, 2009).

Ash-Shiddieqy, Teungku Muhammad Hasbi, Hukum-Hukum Fiqh Islam, (Semarang: Pustaka Rizki Putra, 2001). 
Ash Shiddieqy, Teuku Muhammad Hasbi, Mutiara Hadis 5, Jilid V, (Semarang: Pustaka Rizki Putra, 2003) .

Hadi, Muhammad Sholikul, Pegadaian Syariah, Edisi Pertama. (Jakarta : Salemba Diniyah, 2003).

Huzaemah, Tahido, Pengantar Perbandingan Mazhab, Cet.I, (Jakarta: Logos Wacana Ilmu, 1997) .

Haq, Hamka, Falsafah Ushul Fikih, (Ujung Pandang: Yayasan al-Ahkam, 1998).

Himpunan Fatwa Dewan Syari'ah Nasional, Untuk Lembaga Kenangan Syari'ah, Edisi I, Jakarta: Dewan Syari'ah Nasional Majelis Ulama Indonesia Bank Indonesia, 200).

Idris, Abdul Fatah, Istinbath Hukum Ibnu Qayyim, (Semarang: Pustaka Zaman, 2007). Imam Abi Al-Husein Muslim, "Shahih Muslim", Juz I(Bairut-Libanon : Darul Fikr, tt) . 